\title{
Article \\ Obstacles to Sustainable Entrepreneurship amongst Tourism Students: A Gender Comparison
}

\author{
Vera Butkouskaya $₫$, Francesc Romagosa $₫$ and Maria Noguera * \\ School of Tourism and Hotel Management, Autonomous University of Barcelona, 08193 Bellaterra, Catalonia, \\ Spain; Vera.Butkouskaya@uab.cat (V.B.); Francesc.Romagosa@uab.cat (F.R.) \\ * Correspondence: Maria.Noguera@uab.cat
}

Received: 31 January 2020; Accepted: 26 February 2020; Published: 28 February 2020

\begin{abstract}
Students' start-ups are making a significant contribution towards sustainable entrepreneurship development. Thus, this article examines the obstacles to sustainable entrepreneurship amongst university students of tourism and focuses on gender difference. The empirical analysis was based on data from 290 tourism students' surveys accomplished in Spain, in the period from 2012 to 2018. Descriptive statistics were used for the data analysis and a $t$-test for gender comparison analysis. The research revealed that the students' entrepreneurial intentions did not affect their evaluation of the barriers preventing them from creating their own businesses. The main barriers to new business creation were mainly related to economic factors (both societal and university related), the level of innovation in society, and the students' self-confidence (mostly with regard to interest and motivation). Female students were more conscious of the possible obstacles to new business creation than male students. A significant difference between male and female students regarding personal obstacles was explained by the fact that the females considered their lack of entrepreneurial education as more significant than did the males. In addition, the female students tended to need more economic and practical support than male students. Finally, practical suggestions to encourage sustainable entrepreneurship amongst tourism students are discussed.
\end{abstract}

Keywords: sustainable entrepreneurship; tourism students; gender comparison

\section{Introduction}

Perhaps one of the most prominent topics of current times is sustainable development [1,2]. The sustainable development literature defines sustainability in two main ways. Firstly, sustainability concerns that which is to be sustained (e.g., nature, resources, and community). Secondly, sustainability concerns that which is to be developed (e.g., economy, individuals, and society) [3,4]. Previous studies from the entrepreneurship literature confirmed the role of small businesses in economic development, new job creation, counteracting inflation, increased productivity, and innovation [5-10]. Following recent research into social entrepreneurship and corporate social responsibility, and after examining data from the Global Entrepreneurship Monitor 2019 report, it can be said that entrepreneurs also play an essential role in providing individuals and society with non-economic gains [11]. Interdisciplinary studies from within the sustainable development and social entrepreneurship literature have introduced the concept of "sustainable entrepreneurship". This research places the focus on economic, institutional, and psychological perspectives in discussing the development of people, economy, and society $[4,12]$.

Sustainable entrepreneurship is playing a vital role in the transition towards a more sustainable future $[2,13]$. Small firms are historically the most innovative, playing an essential role in bringing new technologies onto the market. This increases competition as a positive lever of economic development [6,7]. Moreover, following the GEM 2019 report, social entrepreneurship is often associated specifically with young change-makers who are idealistic in nature [11]. Entrepreneurial 
intention is widely accepted in the literature to be the critical factor affecting the actual number of businesses started by individuals [4,5,14,15], including young entrepreneurs [16]. However, research by the International Labour Organization [17] indicates that the young (between 15 and 24 years old) are three times more likely than adults to be unemployed. Researchers comment that, even when they have entrepreneurial intentions, students often desist from starting their own business because they are affected by certain external and internal factors $[14,18]$. They suggest that business organisations and universities should not only develop students' entrepreneurial intentions, but also support them in creating their own businesses $[10,19]$. Governments are implementing policies that support young entrepreneurs [17]. Universities are introducing programmes that involve collaboration with businesses, motivating students to develop their entrepreneurial and experiential skills [14,20,21]. The primary goal of the European Commission has for some years been to tackle youth unemployment by increasing the number of start-ups as a key long-term performance criterion [8,21]. Thus, research into sustainable entrepreneurship amongst the young is a priority $[13,16,22,23]$.

The potential obstacles to new business creation as described in the literature are numerous (e.g., the environment, the universities, internal and personal factors, and so on) $[10,15,18,24]$. However, their true impact has not really been ascertained [25]. Research demonstrates that finance-related factors affect youth entrepreneurial intentions more than do university educational programmes [5]. However, financial incentives are not always possible in difficult economic conditions [25]. Thus, an important area of research is dedicated to analysing the personal traits of young entrepreneurs and the substance of university programmes with the aim of encouraging university students to start their own businesses [15]. For instance, a lack of motivation and interest can be considered as a duel obstacle [18]. Recent studies differ in their estimation of the relative significance of different factors $[14,19,20,26]$. Thus, this article aims to clarify the value of each and, in keeping with the concept of sustainability, to underline the importance of non-financial incentives in sustainable entrepreneurship amongst tourism students.

The tourism sector is heavily dependent on entrepreneurship and cannot survive in the long run if it is not both sustainable and entrepreneurial. However, entrepreneurship, sustainability, and tourism are rarely linked in the research [27]. Some authors have suggested that sustainable entrepreneurship in tourism is a means of obtaining competitive advantage through the implementation of new technologies, an important instrument of social value creation $[5,9,12,27,28]$. The increasing competition between tourist destinations and the demand for new types of tourist products and services naturally requires involvement by the entrepreneurial sector [28]. The innovative power of entrepreneurship can help the economy to adapt dynamically to emerging environmental changes and sustainability challenges $[6,12,28]$. In addressing the importance of sustainable entrepreneurship for the tourism sector, this research focused on examining obstacles towards new business creation among tourism students, with a particular emphasis on gender.

The gender issue, which includes gender equality, is accepted as a topic of interest in the sustainable entrepreneurship literature [2,29]. Increasing the number of female start-ups is a goal for many governments, because empirical findings show that women are underrepresented in this respect [21]. However, researchers consider gender mainly as a factor [1,29] rather than a moderator, and overlook the gender differences analysis. In addition, studying gender differences in sustainable entrepreneurship amongst the young in the tourist sector is specifically critical [30,31]. Although females represent the majority of tourism students [8,15], previous studies have confirmed that female students have lower entrepreneurial intentions than male students [30,32]. Moreover, the recent GEM 2019 report points out the lower number of female social entrepreneurs (it is estimated that $55 \%$ of social entrepreneurs are male and $45 \%$ are female) [11]. Additionally, previous studies have demonstrated that females are more affected by external obstacles. For example, due to the higher level of risk avoidance, the impact of entrepreneurial oriented education programmes on females is lower [14,21,32]. Thus, with the aim of closing such a significant gap, this article compares female and male attitudes towards the main obstacles to new business creation among students in tourism-related programmes. 
Based on the above discussion, this study aimed to review, collate, and prioritise the range of obstacles to sustainable entrepreneurship among tourism students from a gender perspective. The main research questions are: (1) What are the major obstacles to new business creation from the perspective of tourism students with entrepreneurial intention? (2) Are there any differences in students' evaluation of financial and non-financial factors, and formal and informal factors? (3) Are there differences in the perception of obstacles between female and male tourism students?

From the theoretical perspective, in the context of sustainable entrepreneurship research, this study aimed to prioritise the obstacles to new business creation among tourism students. Addressing the sustainable entrepreneurship context, the factors are grouped as financial and non-financial, formal and informal ones. Considering the broad scope of factors that can be barriers to new business creation, such a process will facilitate future research. In addition, in analysing the differences between male and female students in terms of the obstacles they might face in starting businesses, the study makes a valuable contribution to the debate, primarily because gender equity is an essential part of sustainable entrepreneurship, and there is a higher number of female than male students in tourism university courses $[8,15]$.

From a practical perspective, this article aims to demonstrate the value of non-financial motivators rather than financial ones. The former can be important in encouraging economic growth and social development in critical economic conditions. They can provide a fillip to the tourism industry in Spain - the country where the study was carried out-as in recent years it has been facing some challenges [33]. It is especially critical because tourism is the main contributor for the country's economy. This research aimed to show more precisely the ways innovation and development can be encouraged in the tourism sector, which can help to solve the problems of unemployment and economic slowdown. The comparative gender analysis can provide both government and educational institutions with information for making more proactive decisions. Specifically, the content of motivational programmes for female students could be revised accordingly [21]. It is specifically important because females represent the majority of tourism students $[8,15]$ but tend to have lower entrepreneurial intention than males.

This article starts with a literature review, in which the main obstacles to students' sustainable entrepreneurship are presented. Then, the data collection and analysis are explained. Afterwards, the results of the t-test are presented, and conclusions are drawn. The study finishes with a discussion of practical implementations and future research lines.

\section{Literature Review}

\subsection{Student's Role in Sustainable Entrepreneurship in Tourism}

The topic of entrepreneurship includes the study of three categories: why entrepreneurs act; how they act; and, what happens when entrepreneurs act [18,34]. The question "why" is addressed from a "psychological/sociological" aspect [25,34]. The question "how" is answered in terms of the managerial behaviour of the entrepreneur and the decisions which they can take. To answer the question "what", the research focuses on the economic outcomes of the actions of the entrepreneur.

In turn, sustainable entrepreneurship, being a combination of two research lines (sustainable development and social entrepreneurship), follows both economic gains and non-economic outcomes [4,12]. Tourism is one of the economic sectors in which a high degree of involvement by the sustainable entrepreneurial sector is needed. Due to the rapid growth in international markets and fast-changing customer needs, diversification of tourism products and destinations is required. Consequently, innovations are demanded in tourism $[5,9,12]$. The innovative and future-oriented power of sustainable entrepreneurship helps the economy to adapt dynamically to emerging environmental change $[12,28]$. However, it is important to mention that sustainable tourism entrepreneurship has been envisioned in such a way that economic, social, and aesthetic needs can be fulfilled while maintaining cultural heritage, essential ecological processes, biological diversity, and life support systems [28]. 
Sustainable entrepreneurship addresses these issues by focusing on economic, institutional, and psychological perspectives, so that people, economies, and societies can move towards a more sustainable future [4].

More specifically, following the GEM 2019 report, young idealistic entrepreneurs are considered to be most often associated with sustainable entrepreneurship [11]. Particularly, youth entrepreneurship is accepted as a solution to the problem of unemployment $[5,8,10]$. Youth start-ups have innovation potential and facilitate new technology development $[1,6,24]$. Growing on the topic of sustainability, youth also have the ability to modernise society through moral cognition and social value creation $[1,5,24,35]$. Existing research suggests that entrepreneurs with prior knowledge of ecological and social environments, the perceived threats to such environments, and an altruistic attitude towards others have a greater ability to recognise opportunities for sustainable development. Following this, recent research has confirmed that students' start-ups are making a significant contribution towards economic growth, innovation, social value creation, and, in general, sustainable entrepreneurship development $[10,15,24]$.

In Spain, within the service sector, tourism is the main contributor to annual growth. Although sustainable entrepreneurship is considered as a solution for the competitive problem and opportunity to create sustainable advantage in tourism through innovation and social and regional development [12,28], no strategy at the national level to promote that type of entrepreneurship has been developed yet.

\subsection{Obstacles to Students' Entrepreneurship}

Entrepreneurial intention is one of the most important themes in discussions around youth entrepreneurship [5,14,15,18]. Intention and behaviour are highly correlated, and it has been widely accepted in the literature that entrepreneurial intention is directly related to the number of new start-ups $[4,5,14,15,36]$. In turn, the growth of start-ups is a source of entrepreneurship development $[10,15,24]$. However, the students with entrepreneurial intentions may be prevented from starting businesses because of external (macro and micro) factors, internal factors, and personal characteristics $[10,14,18,19,22,37]$. Following the theory of planned behaviour [37], personal traits such as proactiveness, risk perception, or a lack of certain social connections (e.g., family experience with business, family income status, ethnicity, or citizenship) may influence students in whether or not to establish new companies $[5,14,19,20,36,38-40]$.

As mentioned above, sustainable entrepreneurship follows both economic gains and non-economic outcomes [4,12]. It also places the focus on economic, institutional, and psychological perspectives in discussing the development economy and society $[4,12]$. Addressing this, obstacles that inhibit students from opening businesses can be grouped into the following categories: exogenous or external environment (financial and non-financial factors), university related formal and informal factors, and endogenous (personal/individual) formal and informal barriers, amongst others [10,15,20,24]. Trivedi [18] made an initial attempt to put all of these elements together and to develop a new, empirically testable model of students' entrepreneurial intention, namely the entrepreneurial intention-constraint model (EICM). The author based this on the theory of planned behaviour, combining three trait variables, namely attitudes towards behaviour, perceived social norms, and perceived behavioural control [37], with the aforesaid categories.

\subsubsection{Exogenous Environment}

The influence of the external/macro-environment, such as society, the government, or institutions, on entrepreneurial activity can be felt in government financial support, norms, rules, administrative procedures, cultural influences, technological development, availability of relevant education, economic incentives, and so on $[5,15,41]$.

Economic support in obtaining start-up capital plays a significant role in reducing risk perception and positively affects the intention to create a new company $[9,16,18,19,42]$. However, non-financial external factors also have an impact on students. For instance, government support plays an essential 
role in building a student's entrepreneurial intentions $[9,16,21]$. In conditions of economic crisis, the government plays an essential role in nurturing local, homegrown entrepreneurship and encouraging an interest in start-ups in high-tech fields [19]. Furthermore, from the government point of view, particular support for female entrepreneurs, who are recognised to have lower entrepreneurial intentions than males, is needed [14,32]. Additionally, the facilitation of legal processes and the removal of bureaucratic impediments to start-ups can have a positive impact on behaviour $[16,18,19,27]$. Some researchers have suggested that social-cultural norms may affect decisions to open new companies $[9,18,25,27,41]$. In addition, technologies and innovation play an essential role in providing new ideas for start-ups $[9,18,43]$. They may stimulate specifically the creation of new companies by the younger generation, as they are more likely to base their entrepreneurial ideas on new technologies [5,35]. Finally, the lack of an adequate level of education or access to required business education support (e.g., workshops, training, counselling, and mentoring) can reduce the number of start-ups [16,18,19,41].

\subsubsection{University Environment and Support}

The role of the university in building students' entrepreneurial intentions includes formal (structural and educational) and informal (support and incentives) aspects. These factors, in turn, have financial and non-financial implications.

The formal aspects require a focus on establishing learning methods and entrepreneurial-oriented education programmes for students $[8,20,31,44]$. This means that, as a formal institution, the role of the university is to align its objectives and organisational structures with providing educational possibilities. The university should operate as an entrepreneur in terms of being flexible, adaptable, and business-oriented, and should focus on innovation [5,44]. Entrepreneurially oriented teaching methodologies, flexibility, and innovation in educational programmes enable students to obtain the skills needed to gain practical experience $[45,46]$. Entrepreneurially oriented educational programmes in universities have a positive impact on students' entrepreneurial intentions [32]. Entrepreneurial education increases student perception significantly, towards the desirability and feasibility of creating new businesses [14,20,44,47].

Informal university factors include collaboration with the real world of business and the provision of resources and incentives which enhance students' entrepreneurial interest, motivation, and self-efficacy [18-20,24,44]. Financial support includes providing economic help and extra incentives [26,44]. For instance, with the aid of financial support, perceived risks are reduced, and students become more interested and motivated [18]. By providing a creative atmosphere, the university can help students to find new business ideas [26]. Collaborative support from the university is related to building lines of communication between education and the outside world through interaction with successful business owners [20,44]. Real-life examples, mentoring, and advice from practitioners foster the development of students' self-efficacy $[18,20]$. Collaboration with real business help students to build the required networks for starting firms [20].

\subsubsection{Endogenous Barriers}

Endogenous barriers can be formal (related to perceived education and experience) and informal (related to internal motivations and interests). More specifically, formal internal factors are related to students' opinion regarding their perceived levels of education/knowledge and experience during the education $[20,44,45,48]$. They are also related to self-efficacy (i.e., an individual's belief in their ability to perform specific tasks and availability to them of the required skills to create a business) $[14,18,45]$. Haynie et al. [49] argued that the system must provide young people with a better education, demonstrating a wide range of alternatives, helping them to learn how to identify and explore business opportunities. Informal aspects such as level of self-motivation, personal traits, and interest are proven to be directly related to intention $[9,15]$. The perceived high level of risks and stress related to new business creation may decrease the motivation of students, and the lack of time or partners may reduce their interest further $[18,39,45]$. 
Nevertheless, several studies on the topic of obstacles towards student entrepreneurship yield results that may be considered controversial [19]. Despite the prolific research on the relationship between education and entrepreneurial intentions, theoretical and empirical disagreements remain [14]. For instance, findings from Nabi et al. [26] suggest that the influence of entrepreneurial education is variable, and, in some cases, even leads to a decrease in entrepreneurial intention. Arranz et al. [20] pointed out that, contrary to expectations, entrepreneurial education has little effect on the development of entrepreneurial competencies. Thus, different studies report different results regarding the importance of the above factors.

In considering the aforesaid obstacles, we suggest the following hypotheses:

Hypothesis 1 (H1). Students' attitudes towards the importance of obstacles (exogenous, university, or endogenous) preventing them from new business creation vary in intensity.

Hypothesis 1a (H1a). Formal and informal factors have different impact on students' entrepreneurial proactivity.

Hypothesis $\mathbf{1 b}(\mathbf{H} 1 \mathbf{b})$. Financial and non-financial factors have different impacts on the students' entrepreneurial proactivity.

Hypothesis 2 (H2). Some factors (exogenous, university, or endogenous) have a higher impact on students' entrepreneurial proactivity than others.

\subsection{Gender}

The sustainable development of societies, businesses, and, ultimately, countries is affected by a fundamental driving force: gender [2,41]. The gender issue, which includes gender equality, is accepted as a topic of interest in the sustainable entrepreneurship literature [2,29]. Empirical findings show that women are underrepresented as social entrepreneurs, and official reports confirm a smaller number of female start-ups [11,21]. Various studies confirm that men tend to have a higher level of entrepreneurial intention than women $[14,30,32]$. It is traditionally explained by the differences in attitudes between the genders towards factors that affect entrepreneurial intention [38]. A stereotype of entrepreneurs is that males are more entrepreneurial because of a behavioural trait towards risk-taking activity, while women try to avoid the effect of unpredictable exogenous factors [14,32]. Moreover, female students represent the majority of the students in the tourism university courses $[8,15]$. Thus, potentially, the growth of female students' start-ups can be considered as inducement towards sustainable entrepreneurship development in tourism. That is why it is accepted that governmental support for female entrepreneurs is needed.

Previous studies have demonstrated different attitudes of female students towards external obstacles, for example technology [42] and the level of education [41]. In addition, earlier findings show that the entrepreneurial education, as a formal university factor, does not generate equal benefits for all students; the effect is not as great for females [21,32,42]. Due to the higher level of risk avoidance, the impact of entrepreneurial oriented education programmes on females is lower [14,21,32]. Moreover, female students tend to perceive lower the final impact of educational programmes on their knowledge and experience than male students $[21,50]$. Thus, they feel less confident and capable of initiating start-up activity than males [21,51]. It may be the case that females are more risk-averse or realistic when it comes to entrepreneurial proactivity [32]. Additionally, previous research confirms that there is a gender difference in entrepreneurial career aspiration because of the higher perceived value of experience over education amongst females $[19,38]$. This confirms that the fear of failure is stronger amongst women $[21,52]$.

Following that background, we suggest the following hypotheses:

Hypothesis 3 (H3). Female students consider obstacles to opening a new company (external, university, and personal) to be more detrimental to their entrepreneurial activity than male students. 
Hypothesis 4 (H4). There are significant differences in male and female students' attitudes towards obstacles to starting a new company (external, university, personal, formal/informal, and financial/non-financial).

\section{Materials and Methods}

\subsection{Questionnaire}

To measure the entrepreneurial vocation of the youth, we adapted the methodology previously used in the literature [19]. We asked students about their attitude, intention, and behaviour to be an entrepreneur. They could answer yes or no (Table 1). To analyse the barriers to creating a start-up amongst tourism students, the final sample includes only students who showed the attitude and intention to create a new company but who had not yet done so.

Table 1. Survey items.

\begin{tabular}{|c|c|c|}
\hline Factor & Code & Item \\
\hline \multicolumn{3}{|c|}{$\begin{array}{c}\text { Entrepreneurial vocation } \\
\text { (Answer Yes or No to the following questions) }\end{array}$} \\
\hline $\begin{array}{l}\text { Entrepreneurial attitude } \\
\text { Entrepreneurial intention } \\
\text { Entrepreneurial behaviour }\end{array}$ & $\begin{array}{l}\text { EA } \\
\text { EI } \\
\text { EB }\end{array}$ & $\begin{array}{c}\text { "Do you consider it desirable to create or start your own company?" } \\
\text { "Have you ever considered becoming an entrepreneur?" } \\
\text { "I have created company already ..." }\end{array}$ \\
\hline \multicolumn{3}{|r|}{$\begin{array}{l}\text { Exogenous environment } \\
\text { g environmental factors favour the creation of new companies today. * } \\
1 \text { (not important) to } 5 \text { (very important). }\end{array}$} \\
\hline \multicolumn{3}{|r|}{ Financial } \\
\hline Economic & EXT-ECON & Access to financial resources \\
\hline \multicolumn{3}{|r|}{ Non-financial } \\
\hline Educational & EXT-EDU & Better level of education \\
\hline Legal & EXT-LEGAL & Less bureaucracy and administrative procedures \\
\hline Social-cultural & EXT-SOC-C & Social and cultural norms \\
\hline Technological & EXT-TECH & Development of new technologies \\
\hline Political & EXT-POLIT & Government support \\
\hline Support for females & EXT-FEM & Support for the entrepreneurial woman \\
\hline
\end{tabular}

University/Institutional factors

Which of the following aspects related to university do you think could be an obstacle or a difficulty if a student, professor or researcher wished to create a company?

Rate from 1 (not important) to 5 (very important).

\begin{tabular}{|c|c|c|}
\hline \multicolumn{3}{|r|}{ Formal } \\
\hline \multirow{4}{*}{$\begin{array}{l}\text { University structure } \\
\text { (flexible, adaptable, and business } \\
\text { oriented) } \\
\text { Educational programmes } \\
\text { (entrepreneurial oriented, flexible, } \\
\text { and innovative) }\end{array}$} & UNI-FORM1 & \multirow{4}{*}{$\begin{array}{c}\text { University's objectives are not entrepreneurially oriented } \\
\text { University's organisational structure and management are not flexible } \\
\text { Teaching objectives are not entrepreneurial oriented }\end{array}$} \\
\hline & UNI-FORM2 & \\
\hline & UNI-EDU1 & \\
\hline & UNI-EDU2 & \\
\hline \multicolumn{3}{|r|}{ Informal } \\
\hline \multirow{4}{*}{$\begin{array}{l}\text { Collaboration with business world } \\
\text { University support } \\
\text { (financial support and } \\
\text { non-financial incentive) }\end{array}$} & UNI-BUS1 & \multirow{4}{*}{$\begin{array}{c}\text { Inadequate relationships with the business world } \\
\text { Lack of infrastructure (i.e., business incubators) to create new com } \\
\text { Lack of economic aid to create new companies } \\
\text { Lack of non-financial incentives in creating a company }\end{array}$} \\
\hline & UNI-BUS2 & \\
\hline & UNI-I1 & \\
\hline & UNI-I2 & \\
\hline
\end{tabular}

Endogenous barriers

Which of the following aspects related to the entrepreneur person do you think could be an obstacle or a difficulty if a student, professor or researcher wished to create a company? Rate from 1 (not important) to 5 (very important).

\begin{tabular}{ccc}
\hline & \multicolumn{3}{c}{ Formal } \\
\hline $\begin{array}{c}\text { Perceived experience and } \\
\text { education }\end{array}$ & $\begin{array}{c}\text { PERS-EXP } \\
\text { PERS-EDU }\end{array}$ & $\begin{array}{c}\text { Lack of experience to create a company } \\
\text { Lack of training to conduct a business }\end{array}$ \\
\hline Internal motivation and Interest & PERS-MOT & Informal \\
& PERS-INT & $\begin{array}{c}\text { Lack of entrepreneurial spirit } \\
\text { Lack of interest to create a company }\end{array}$ \\
\hline
\end{tabular}


Following the literature review, the questions regarding the obstacles to creating a new business were adapted from various sources, and they were grouped as: Exogenous environment (including financial and non-financial environmental factors, such as economic [9,16,18,19,42], educational $[16,18,19,41]$, legal $[16,18,19,27]$, social-cultural $[9,18,25,27,41]$, technological $[5,18,35,43]$, political [9,16,21], and female support [14,32]); University/Institutional factors (divided into formal aspects, such as university structure or educational programmes $[5,8,20,31,44]$, and informal aspects, such as the collaboration with the business world or the university support [18-20,24,26,44]); and Endogenous barriers (divided into formal, such as the perceived experience and education $[14,18,20,44,45,48]$, and informal, such as the internal motivation and interest $[9,15,18,39,45])$.

The original questionnaire consisted of closed questions. Reverse questions were included to encourage careful reading of the statements. Factors regarding students' attitudes towards creating a new company were measured on a five-point Likert scale (from 1 "not important" to 5 "very important").

\subsection{Sample}

Primary data were collected using an online survey of university students of tourism and hospitality. The anonymity of the survey was guaranteed. The study was conducted at the School of Tourism and Hotel Management of the Autonomous University of Barcelona, Catalonia, Spain, in the period from 2012 to 2018 (seven survey rounds, one per year). In such a context, the response rate was very high. Only a small number of questionnaires lacked consistency or were incomplete; these were rejected. In addition, some fixed parameters were included, such as age, employment status, family income, and gender.

The original full sample consisted of 454 responses. Because the specific intention was to analyse student perceptions regarding factors which can be considered as obstacles to starting a new company, only those with entrepreneurial attitude and intention were selected. Thus, 154 respondents $(33.9 \%)$ who answered no to the question about entrepreneurial intention and 10 respondents $(2.2 \%)$ who had already created their own companies were eliminated from the original sample.

The final sample consisted of 290 respondents (Table 2). It appears that $72.4 \%$ were female, and $27.5 \%$ were male. The age range was 18.5 to 31.1 years; the average age was 24.8 years.

Table 2. The sample.

\begin{tabular}{cccc}
\hline \multicolumn{2}{c}{ Number of Respondents } & \multicolumn{2}{c}{ Number of Respondents } \\
\hline Gender & 80 & Less than $1000 €$ & 42 \\
\hline Male $(\mathrm{M}=1)$ & 210 & Between 1000 and $2000 €$ & 88 \\
\hline Female $(\mathrm{F}=0)$ & 290 & Between 2000 and $4000 €$ & 98 \\
\hline Total & & Between 4000 and $7000 €$ & 40 \\
\hline Employment status & 154 & Between 7000 and $10,000 €$ & 12 \\
\hline Working & 136 & More than $10,000 €$ & 10 \\
\hline Not working & 290 & Total & 290 \\
\hline Total & &
\end{tabular}

\subsection{Data Analysis}

Data analysis was carried out using SPSS ver. 22 (IBM, Armonk, NY, USA) and Microsoft Excel 2010 (Microsoft Corporation, Redmond, WA, USA). The following statistical models were used: frequency analysis descriptive measures, a graphical method, and a sample $t$-test for a comparison of mean differences. During the data collection, we used the five-point Likert scale. All factors with a mean of more than three were accepted to be critical. The results of the data analysis are presented in Table 3. 
Table 3. $t$-test results including comparative gender analysis.

\begin{tabular}{|c|c|c|c|c|c|c|c|c|}
\hline \multirow[t]{3}{*}{ Variable } & \multirow{2}{*}{\multicolumn{2}{|c|}{$\begin{array}{c}\text { Full Sample } \\
(\mathrm{n}=290)\end{array}$}} & \multirow{2}{*}{\multicolumn{2}{|c|}{$\begin{array}{l}\text { Females } \\
(n=210)\end{array}$}} & \multicolumn{2}{|c|}{ Males } & \multirow{2}{*}{\multicolumn{2}{|c|}{$t$-test $(\mathrm{df}=290)$}} \\
\hline & & & & & \multicolumn{2}{|c|}{$(\mathrm{n}=80)$} & & \\
\hline & M & SD & M & SD & M & SD & \multicolumn{2}{|l|}{$t$-value } \\
\hline \multicolumn{9}{|c|}{ Exogenous Environment } \\
\hline \multicolumn{9}{|c|}{ Financial Factors } \\
\hline EXT-ECON & 4.49 & 0.872 & 4.54 & 0.838 & 4.31 & 0.952 & $2.493 *$ & $\mathrm{~S}$ \\
\hline \multicolumn{9}{|c|}{ Non-Financial Factors } \\
\hline EXT-TECH & 4.20 & 0.792 & 4.22 & 0.794 & 4.13 & 0.786 & 1.000 & $\mathrm{R}$ \\
\hline EXT-EDU & 4.09 & 0.849 & 4.15 & 0.826 & 3.92 & 0.898 & $2.487^{*}$ & $\mathrm{~S}$ \\
\hline EXT-POLIT & 4.01 & 0.954 & 4.05 & 0.935 & 3.88 & 1.002 & 1.652 & $\mathrm{R}$ \\
\hline EXT-FEM & 3.97 & 1.011 & 4.11 & 0.934 & 3.55 & 1.122 & $5.159 * *$ & $S$ \\
\hline EXT-LEGAL & 3.80 & 0.934 & 3.83 & 0.890 & 3.69 & 1.056 & 1.407 & $\mathrm{R}$ \\
\hline EXT-SOC-C & 3.79 & 0.882 & 3.83 & 0.863 & 3.65 & 0.930 & 1.873 & $\mathrm{R}$ \\
\hline \multicolumn{9}{|c|}{ University } \\
\hline \multicolumn{9}{|c|}{ Informal Factors (incentives and connections with real business) } \\
\hline UNI-I1 & 4.16 & 0.924 & 4.24 & 0.881 & 3.91 & 1.010 & $3.331^{* *}$ & $S$ \\
\hline UNI-I2 & 3.96 & 1.003 & 4.02 & 0.971 & 3.78 & 1.079 & 2.174 * & $S$ \\
\hline UNI-BUS2 & 3.80 & 1.007 & 3.86 & 1.009 & 3.62 & 0.983 & 2.134 * & $S$ \\
\hline UNI-BUS1 & 3.64 & 0.933 & 3.71 & 0.940 & 3.45 & 0.890 & $2.452 *$ & $S$ \\
\hline \multicolumn{9}{|c|}{ Formal Factors (formal structure and educational programs) } \\
\hline UNI-FORM1 & 3.62 & 0.899 & 3.63 & 0.899 & 3.61 & 0.905 & 0.169 & $\mathrm{R}$ \\
\hline UNI-EDU2 & 3.62 & 1.069 & 3.65 & 1.077 & 3.54 & 1.045 & 0.945 & $\mathrm{R}$ \\
\hline UNI-FORM3 & 3.46 & 0.884 & 3.48 & 0.884 & 3.43 & 0.888 & 0.513 & $\mathrm{R}$ \\
\hline UNI-EDU1 & 3.42 & 0.823 & 3.43 & 0.819 & 3.36 & 0.837 & 0.806 & $\mathrm{R}$ \\
\hline \multicolumn{9}{|c|}{ Endogenous barriers } \\
\hline \multicolumn{9}{|c|}{ Informal Factors } \\
\hline PERS-MOT & 4.21 & 0.950 & 4.24 & 0.963 & 4.13 & 0.908 & 1.032 & $\mathrm{R}$ \\
\hline PERS-INT & 4.13 & 1.067 & 4.20 & 1.021 & 3.93 & 1.182 & $2.835^{*}$ & $\mathrm{R}$ \\
\hline \multicolumn{9}{|c|}{ Formal Factors } \\
\hline PERS-EDU & 3.90 & 0.946 & 3.97 & 0.955 & 3.68 & 0.884 & $2.303 *$ & $S$ \\
\hline PERS-EXP & 3.89 & 0.976 & 3.92 & 0.985 & 3.81 & 0.949 & 0.971 & $\mathrm{R}$ \\
\hline
\end{tabular}

Note. M, mean; SD, standard deviation; $\mathrm{df}$, degrees of freedom; $p, p$-value. Factors are rated from 1 (not important) to 5 (very important). Decision about differences in means: $\mathrm{R}$, rejected; $\mathrm{S}$, supported. ${ }^{*} p<0.05,{ }^{* *} p<0.001$.

Results from the comparative mean analysis show that the students perceived the importance of various factors differently. Among exogenous factors, the most serious obstacles were the following: economic, technological, educational, and political with the $\mathrm{M}$ (mean) above 4 in the range from 0 to 5. Among university-related factors, the most important were informal (incentives and real business connections). Informal endogenous factors (motivation and interest) were more important than formal one (perceived education and experience). Thus, $\mathrm{H} 1$ was confirmed; students had different attitudes towards factors that could be considered obstacles to new business creation.

Informal university and informal endogenous obstacles were perceived to be greater than formal ones. Thus, H1a was confirmed. In addition, both financial exogenous and university factors were considered to be more critical than non-financial ones. Therefore, the results confirm H1b. Amongst the factors analysed, formal university factors (structure and educational programmes) were considered to be the least critical of all. Thus, $\mathrm{H} 2$ was also confirmed.

The gender analysis showed that female students regarded all the obstacles as more valuable than did the male students. This confirmed H3. More specifically, there were significant differences 
in the evaluation of exogenous factors between female and male students: economic $(\mathrm{Mf}=4.54$ and $\mathrm{Mm}=4.31, \mathrm{t}(290)=2.493, p<0.05)$, educational $(\mathrm{Mf}=4.15$ and $\mathrm{Mm}=3.95, t(290)=2.487, p<0.05)$, and legal support for female entrepreneurs $(\mathrm{Mf}=4.11$ and $\mathrm{Mm}=3.55, t(290)=5.152, p<0.001)$.

There were also significant differences in informal and financial university-related barriers, more specifically in the evaluation of the importance of incentives (UNI-I1: $\mathrm{Mf}=4.24$ and $\mathrm{Mm}=3.91$, $t(290)=3.331, p<0.001$ and UNI-I2: $\mathrm{Mf}=4.02$ and $\mathrm{Mm}=3.78, t(290)=2.174, p<0.05)$. In addition, female students saw the university link to real business as significantly more critical than male students-more specifically, insufficient relationships with the business world ( $\mathrm{Mf}=3.86$ and $\mathrm{Mm}=3.62, t(290)=2.134, p<0.05)$ and lack of infrastructure (business incubators and so on)-in the attitude or intention to create companies $(\mathrm{Mf}=3.71$ and $\mathrm{Mm}=3.45, t(290)=2.252, p<0.05)$.

In the evaluation of personal factors, female students evaluated their perceived entrepreneurial education as a significantly more critical informal endogenous factor $(\mathrm{Mf}=3.97$ and $\mathrm{Mm}=3.68$, $t(290)=2.303, p<0.05)$. This confirmed H4; female students evaluated financial and informal barriers as being more important than did male students.

\section{Discussion}

From the theoretical perspective, the research results confirm the significance of all the factors (exogenous, university-related, and endogenous) that were analysed. Notably, it supports the previous suggestions on the role of the following exogenous factors: economic $[9,16,18,19,42]$; educational $[16,18,19,41]$; technological $[9,18,43]$; government support $[9,16,21]$, including support for females [14,32]; legal [16,18,19,27]; and socio-cultural [9,18,25,27,41]. Financial factors were considered to be the greatest hindrance [5]. However, students evaluated all other factors as being almost as important. Following calls in previous research to find a new non-financial way to motivate students to start new businesses [25], this study demonstrates that, even though it is not the most central element, tourism students evaluate very highly the impact of non-financial informal motivation.

Moreover, the study supports prior research that noted the critical role of both formal [8,20,44,47] and informal [18-20,24,44] university-related factors. Many earlier studies are focused on the analysis of the formal factors and impact of entrepreneurial education on students' entrepreneurship [14,20,32,44,47]. However, this research demonstrates that students considered formal university factors (such as structures and educational programmes) of least significance. The lack of informal factors (such as incentives and connections with real business) are more damaging to their entrepreneurial development than formal factors. This confirms the role of context (such as interactions between market actors) for the sustainable entrepreneurship development. In addition, this research strengthens a previous suggestion that, amongst university-related factors, students regarded financial motivators to be more significant than education programmes [5].

In addition, this research advances the suggestion made in previous studies regarding the vital role of endogenous barriers, both formal (such as perceived levels of education and experience) $[16,20,45,48]$ and informal (such as motivation and interest) $[9,15]$, as obstacles to the creation of new businesses amongst the young $[15,18]$. The outcomes of the analysis also indicate that informal factors are more relevant than formal ones.

Additionally, the results of the comparative gender analysis support recent research that has demonstrated that females evaluate more critically than male students all factors relating to new business creation [14,21,32]. It holds the suggestion that women are more risk-averse to the idea of starting companies than men [38]. Moreover, there are some significant differences in factor evaluation between female and male students. As was expected, support for female entrepreneurs was significantly more important for female students than for male students. However, that is not the most critical factor for females. They value (significantly more than males) stronger financial support (at both government and university levels), and the availability of education and training in the region. In addition, internal motivation and interest are more important for female young entrepreneurs than 
female support programmes. It may be that financial support reduces risk aversion, which affects female more than male potential entrepreneurs [14,32].

From a practical perspective, as demonstrated above, to increase the number of new start-ups, economic support should be provided both at the government and university levels [5], although non-financial factors also play a critical role. Students are interested in creating innovative start-ups, which is the fuel for the sustainable entrepreneurship. Thus, government policies should focus more on the development of new technology, which could have a positive impact on the number of innovative student projects. It could further provide an additional competitive advantage for some tourist destinations by increasing the attractiveness and popularity of services. In addition, the support for the students can also include incentives or tax discounts. Additionally, given the responses to university-related factors (especially the results showing informal factors to be more important than formal), universities should implement programmes with a focus on developing collaboration with businesses and motivating students towards developing entrepreneurial skills and building up their experience $[14,20,21]$.

Specifically, based on the research results regarding university-related factors, considerable attention should be dedicated to encouraging students to recognise the value of educational programmes. Previous studies confirm the value of entrepreneurial education to the students' perception of the desirability and feasibility of new business creation $[14,20,44,47]$. However, interestingly, the participants valued more informal university-related factors (such as incentives and collaboration with real business). This may be because students tend to neglect the role of education as a facilitator in new business creation $[21,50]$.

As informal factors are important, universities should also focus on building real-life collaborations with businesses [20,44]. These provide students with opportunities to build business networks, to experience real-life examples, to obtain mentoring, and to receive advice from practitioners $[18,20]$. Additionally, as has been suggested previously [18-20,24,44], students have appreciated incentives in the form of physical facilities. Providing work and collaborative spaces, developing creative areas, and establishing groups to facilitate the creation of new ideas can have a positive impact on sustainable entrepreneurship [26].

Endogenous factors (both perceived education/knowledge and motivation/interest) are the most important. Thus, the research confirms that both external agencies and universities should not only develop students' entrepreneurial intentions but also cultivate a positive attitude towards creating their own businesses $[10,19]$. Providing more opportunities to acquiring real-life experience (i.e., boosting experiential learning) could help to solve the problem of unemployment and increase levels of the students' self-confidence [45]. This, in turn, may help to increase the number of start-ups by the young generation.

Increasing female start-up activity is a priority for many governments because empirical findings have shown that women are underrepresented in new business creation [21]. However, more than the positive effect of "female support" programmes [14,32], female students in tourism expect financial and non-financial support. This could be in the form of economic aid, incentives, and opportunities to collaborate with real businesses. Interestingly, female students feel less self-confident regarding their level of education than male $[21,50]$. Thus, more entrepreneurially oriented courses should be offered to female students.

The study supports the validity of female entrepreneurs' programmes; these have already been developed and implemented at governmental level.

\section{Conclusions, Limitations and Future Lines of Research}

Motivated by the need to prioritise research in the area of sustainable entrepreneurship [2,29-31], specifically among youth $[13,16,22,23]$, this study focused on three main points of analysis. Firstly, it analysed and prioritised the factors that can be the obstacles to new business creation among youth. As has been noted, findings confirm the significant value of the all the factors that have been considered 
herein $[14,19,20,26]$. Secondly, it contributes to the sustainable research agenda by focusing on the comparative analysis of financial, non-financial, formal, and informal factors. It makes a valuable contribution to research given that the focus of sustainable entrepreneurship is mainly on economy and society $[4,12]$. Thirdly, it attempts to come to a more in-depth understanding of the gender effect on the evaluation of obstacles among tourism students. It also contributes towards the gender aspect of sustainable entrepreneurship research [2,29].

Finally, the focus of this research on the analysis of Spanish tourism students' entrepreneurial activity contributes towards ensuring the sustainable development of the Spanish economy, and thus its society. This study is especially valuable given that Spanish tourism has experienced several challenges in recent years [33].

Based on the data from a survey of 290 tourism students in Spain, this article presents the results of an in-depth empirical analysis of exogenous, university-related, and endogenous factors to provide theoretical and practical input.

As a main conclusion, our study shows that students, even those with entrepreneurial intentions, see different obstacles (external, university-related, and internal) to new business creation [14,18]. Financial factors, external and university-related (such as access to the financial resources and university aid to create new companies), represent the most critical ones affecting the entrepreneurial intentions of tourism students. However, there is also a notable number of non-financial factors that are very important for tourism students. For example, the level of new technological development and access to better education as external factors; non-financial incentives and infrastructure (i.e., business incubators) to create new companies as university-related factors; and the level of motivation and interest as internal factors. Moreover, the informal factors, both university-related and internal, are considered by students as more important than formal ones. Thus, the research demonstrates that not only financial motivators are valued by the students. Students perceive at a high level the value of non-financial and informal motivators for new business creation. Following this, we could assume that the youth entrepreneurs, as their values align with the social oriented objectives, are the future of the sustainable entrepreneurship. In other words, the growth in number of students' start-ups is an antecedent of the sustainable entrepreneurship development.

The gender comparison analysis confirms that female students evaluate all factors as more critical than males (significantly more, financial and educational). As a main conclusion, female students have higher level of risk aversion. However, they do not see the government support as the most useful solution. Females evaluate more than males the following factors: financial incentives, education availability, and personal motivation and interest.

As a main practical implementation, this research underlines the possibility of using factors other than financial motivators (such as technology development or business incubators). Government policies on the development of new technology can increase the number of innovative start-ups. On its part, university practices towards developing business incubators and facilitating real business connections can help students to develop the social context (business network). As a result, both non-financial and informal motivators will fuel the sustainable entrepreneurship. Moreover, putting into practice the fact that students underestimate the valuable role of entrepreneurially oriented educational programmes $[14,20,44,47]$, universities should review their strategies and make these programmes more interesting.

Furthermore, considering the significant higher number of tourism management students [8,15], to cultivate the development of sustainable entrepreneurship in tourism, governments may review the "female support" programmes. Moreover, more entrepreneurial oriented educational programmes should be offered to females, as they evaluate their perceived value of education as a critical factor compared to males.

As with any study, thus study has some limitations. It only included respondents from one tourism school in a single country (Spain). Future studies might include gender comparisons of students with various specialisations from different countries. In addition, future research could investigate in more 
detail the difference between female and male students' attitudes towards entrepreneurial education programmes. Previous research has suggested that entrepreneurial education may be detrimental to entrepreneurial intention [26]. However, our results demonstrate that female students' value highly the role of education in this regard.

Author Contributions: Conceptualisation, V.B., F.R., and M.N.; methodology, V.B. and M.N.; data curation and results analysis, V.B.; writing — original draft preparation, V.B.; writing—review, V.B., F.R., and M.N.; and editing, F.R. All authors have read and agreed to the published version of the manuscript.

Funding: This research was funded by the Catalan Agency of University Research (AGAUR), grant number 2017 SGR 1715.

Acknowledgments: We would like to thank the Entrepreneurial Initiatives Center (CIEU) of the Autonomous University of Barcelona for providing us with the data used in this study.

Conflicts of Interest: The authors declare no conflict of interest.

\section{References}

1. Chen, F.W.; Fu, L.W.; Wang, K.; Tsai, S.B.; Su, C.H. The Influence of Entrepreneurship and Social Networks on Economic Growth-From a Sustainable Innovation Perspective. Sustainability 2018, 10, 2510. [CrossRef]

2. Vinokurova, N. Sustainable entrepreneurship and women in science and education: Gender equality, gender inequality. Entrepr. Sustain. Issues 2015, 2, 220-232. [CrossRef]

3. Stock, P.; Burton, R.J.F. Defining terms for integrated (multi-inter-trans-disciplinary) sustainability research. Sustainability 2011, 3, 1090-1113. [CrossRef]

4. Shepherd, D.A.; Patzelt, H. The New Field of Sustainable Entrepreneurship: Studying Entrepreneurial Action Linking "What Is to Be Sustained" With “What Is to Be Developed". Entrepr. Theory Pract. 2011, 35, 137-163. [CrossRef]

5. Altinay, L.; Sigala, M.; Waligo, V. Social value creation through tourism enterprise. Tour. Manag. 2016, 54, 404-417. [CrossRef]

6. Audretsch, D.B.; Bönte, W.; Keilbach, M. Entrepreneurship capital and its impact on knowledge diffusion and economic performance. J. Bus. Ventur. 2008, 23, 687-698. [CrossRef]

7. Audretsch, D.B.; Link, A.N. The fountain of knowledge: An epistemological perspective on the growth of U.S. SBIR-funded firms. Int. Entrep. Manag. J. 2019, 15, 1103-1113. [CrossRef]

8. Del Río, M.D.L.C.; Peris-Ortiz, M.; Álvarez-García, J.; Rueda-Armengot, C. Entrepreneurial intentions and entrepreneurship education to University students in Portugal. Technol. Innov. Educ. 2016, 2, 7. [CrossRef]

9. Fu, H.; Okumus, F.; Wu, K.; Köseoglu, M.A. The entrepreneurship research in hospitality and tourism. Int. J. Hosp. Manag. 2019, 78, 1-12. [CrossRef]

10. Rusu, V.; Roman, A. Entrepreneurial activity in the EU: An empirical evaluation of its determinants. Sustainability 2017, 9, 1679. [CrossRef]

11. Bosma, N.S.; Schott, T.; Terjesen, S.A.; Kew, P. Special Topic Report. Social Entrepreneurship. Global Entrepreneurship Monitor (GEM). Available online: http://www.gem-spain.com/wp-content/uploads/2015/ 03/gem-2015-special-report-on-social-entrepreneurship.pdf (accessed on 28 December 2019).

12. Dean, T.J.; McMullen, J.S. Toward a theory of sustainable entrepreneurship: Reducing environmental degradation through entrepreneurial action. J. Bus. Ventur. 2007, 22, 50-76. [CrossRef]

13. Belz, F.M.; Binder, J.K. Sustainable Entrepreneurship: A Convergent Process Model. Bus. Strateg. Environ. 2017, 26, 1-17. [CrossRef]

14. Bae, T.J.; Qian, S.; Miao, C.; Fiet, J.O. The relationship between entrepreneurship education and entrepreneurial intentions: A meta-analytic review. Entrep. Theory Pract. 2014, 38, 217-254. [CrossRef]

15. Gurel, E.; Altinay, L.; Daniele, R. Tourism students' entrepreneurial intentions. Ann. Tour. Res. 2010, 37, 646-669. [CrossRef]

16. Atef, T.M.; Al-Balushi, M. Entrepreneurship as a means for restructuring employment patterns. Tour. Hosp. Res. 2015, 15, 73-90. [CrossRef]

17. International Labour Organisation (ILO). Youth Unemployment. Available online: https://www.ilo.org/ global/topics/dw4sd/themes/youth-employment/lang--en/index.htm (accessed on 21 September 2019). 
18. Trivedi, R.H. Entrepreneurial-intention constraint model: A comparative analysis among post-graduate management students in India, Singapore and Malaysia. Int. Entrep. Manag. J. 2017, 13, 1239-1261. [CrossRef]

19. Wang, C.K.; Wong, P.K. Entrepreneurial interest of university students in Singapore. Technovation 2004, 24, 163-172. [CrossRef]

20. Arranz, N.; Ubierna, F.; Arroyabe, M.F.; Perez, C.; Fdez. de Arroyabe, J.C. The effect of tourism education on students' entrepreneurial vocation. Scand. J. Hosp. Tour. 2017, 17, 312-330. [CrossRef]

21. Johansen, V. Entrepreneurship education and start-up activity: A gender perspective. Int. J. Gend. Entrep. 2013, 5, 216-231. [CrossRef]

22. Shirokova, G.; Osiyevskyy, O.; Bogatyreva, K. Exploring the intention-behavior link in student entrepreneurship: Moderating effects of individual and environmental characteristics. Eur. Manag. J. 2016, 34, 386-399. [CrossRef]

23. Solvoll, S.; Alsos, G.A.; Bulanova, O. Tourism Entrepreneurship-Review and Future Directions. Scand. J. Hosp. Tour. 2015, 15, 120-137. [CrossRef]

24. Guerrero, M.; Urbano, D.; Fayolle, A. Entrepreneurial activity and regional competitiveness: Evidence from European entrepreneurial universities. J. Technol. Transf. 2016, 41, 105-131. [CrossRef]

25. Wang, S.; Hung, K.; Huang, W.J. Motivations for entrepreneurship in the tourism and hospitality sector: A social cognitive theory perspective. Int. J. Hosp. Manag. 2019, 78, 78-88. [CrossRef]

26. Nabi, G.; Walmsley, A.; Liñán, F.; Akhtar, I.; Neame, C. Does entrepreneurship education in the first year of higher education develop entrepreneurial intentions? The role of learning and inspiration. Stud. High. Educ. 2018, 43, 452-467. [CrossRef]

27. Crnogaj, K.; Rebernik, M.; Bradac Hojnik, B.; Omerzel Gomezelj, D. Building a model of researching the sustainable entrepreneurship in the tourism sector. Kybernetes 2014, 43, 377-393. [CrossRef]

28. Lordkipanidze, M.; Brezet, H.; Backman, M. The entrepreneurship factor in sustainable tourism development. J. Clean. Prod. 2005, 13, 787-798. [CrossRef]

29. Hosseininia, G.; Ramezani, A. Factors Influencing Sustainable Entrepreneurship in Small and Medium-Sized Enterprises in Iran: A Case Study of Food Industry. Sustainability 2016, 8, 1010. [CrossRef]

30. Haus, I.; Steinmetz, H.; Isidor, R.; Kabst, R. Gender effects on entrepreneurial intention: A meta-analytical structural equation model. Int. J. Gend. Entrep. 2013, 5, 130-156. [CrossRef]

31. Zhang, Z.; Zyphur, M.J.; Narayanan, J.; Arvey, R.D.; Chaturvedi, S.; Avolio, B.J.; Lichtenstein, P.; Larsson, G. The genetic basis of entrepreneurship: Effects of gender and personality. Organ. Behav. Hum. Dec. 2009, 110, 93-107. [CrossRef]

32. Westhead, P.; Solesvik, M.Z. Entrepreneurship education and entrepreneurial intention: Do female students benefit? Int. Small Bus. J. 2016, 34, 979-1003. [CrossRef]

33. Albaladejo, I.P.; González-Martínez, M. Congestion affecting the dynamic of tourism demand: Evidence from the most popular destinations in Spain. Curr. Issues Tour. 2019, 22, 1638-1652. [CrossRef]

34. Stevenson, H.H.; Jarillo, J.C. A paradigm of entrepreneurship: Entrepreneurial management. In Entrepreneurship: Concepts, Theory and Perspective; Cuervo, Á., Ribeiro, D., Roig, S., Eds.; Springer: Berlin, Germany, 2007; pp. 155-170.

35. Urbano, D.; Toledano, N. The systems of university education and their influence on the students' attitudes in the business world: A multiple case study. Oikos 2008, 25, 87-103.

36. Autio, E.; Keeley, H.R.; Klofsten, M.; Parker, G.G.C.; Hay, M. Entrepreneurial intent among students in Scandinavia and in the USA. Enterpr. Innov. Manag. Stud. 2001, 2, 145-160. [CrossRef]

37. Ajzen, I. Attitudes, traits, and actions: Dispositional prediction of behavior in personality and social psychology. Adv. Exp. Soc. Psychol. 1987, 20,1-63. [CrossRef]

38. Adachi, T.; Hisada, T. Gender differences in entrepreneurship and intrapreneurship: An empirical analysis. Small Bus. Econ. 2017, 48, 447-486. [CrossRef]

39. Altinay, L.; Madanoglu, M.; Daniele, R.; Lashley, C. The influence of family tradition and psychological traits on entrepreneurial intention. Int. J. Hosp. Manag. 2012, 31, 489-499. [CrossRef]

40. Crant, J.M. The proactive personality scale as a predictor of entrepreneurial intentions. J. Small Bus. Manag. 1996, 34, 42-49.

41. Aparicio, S.; Urbano, D.; Audretsch, D.; Noguera, M. Female and male entrepreneurship during the economic crisis: An institutional tale of European countries. Rev. Econ. Mund. 2019, 51, 163-184. 
42. Zhang, Y.; Duysters, G.; Cloodt, M. The role of entrepreneurship education as a predictor of university students' entrepreneurial intention. Int. Entrep. Manag. J. 2014, 10, 623-641. [CrossRef]

43. Law, K.M.; Breznik, K. Impacts of innovativeness and attitude on entrepreneurial intention: Among engineering and non-engineering students. Int. J. Technol. Des. Ed. 2017, 27, 683-700. [CrossRef]

44. Saeed, S.; Yousafzai, S.Y.; Yani-De-Soriano, M.; Muffatto, M. The Role of Perceived University Support in the Formation of Students' Entrepreneurial Intention. J. Small Bus. Manag. 2015, 53, 1127-1145. [CrossRef]

45. Daniel, A.D.; Costa, R.A.; Pita, M.; Costa, C. Tourism Education: What about entrepreneurial skills? J. Hosp. Tour. Manag. 2017, 30, 65-72. [CrossRef]

46. Sánchez, J.C. The impact of an entrepreneurship education program on entrepreneurial competencies and intention. J. Small Bus. Manag. 2013, 51, 447-465. [CrossRef]

47. Peterman, N.E.; Kennedy, J. Enterprise Education: Influencing Students' Perceptions of Entrepreneurship. Entrep. Theory Pract. 2003, 28, 129-144. [CrossRef]

48. Yun, C. Does entrepreneurship education matter students' entrepreneurial intention? A Chinese perspective. In Proceedings of the 2nd International Conference on Information Science and Engineering, Hangzhou, China, 4-6 December 2010; IEEE: Hangzhou, China, 2010; pp. 2776-2779.

49. Haynie, J.M.; Shepherd, D.A.; Patzelt, H. Cognitive adaptability and an entrepreneurial task: The role of metacognitive ability and feedback. Entrep. Theory Pract. 2012, 36, 237-265. [CrossRef]

50. Wilson, F.; Kickul, J.; Marlino, D. Gender, entrepreneurial self-efficacy, and entrepreneurial career intentions: Implications for entrepreneurship education. Entrep. Theory Pract. 2007, 30, 387-406. [CrossRef]

51. Kirkwood, J. Is a lack of self-confidence hindering women entrepreneurs? Int. J. Gen. Entrepr. 2009, 1, 118-133. [CrossRef]

52. Wagner, J. What difference a Y makes-Female and male nascent entrepreneurs in Germany. Small Bus. Econ. 2007, 28, 1-21. [CrossRef]

(C) 2020 by the authors. Licensee MDPI, Basel, Switzerland. This article is an open access article distributed under the terms and conditions of the Creative Commons Attribution (CC BY) license (http://creativecommons.org/licenses/by/4.0/). 